\title{
Controversies on Public Religious Pedagogy: religious education in times of post-democratic populism, global warming and economization of education
}

\author{
Jan-Hendrik Herbst ${ }^{1}$ (D) \\ Published online: 19 March 2020 \\ (c) The Author(s) 2020
}

\begin{abstract}
In times of social crises, Public Religious Pedagogy is emerging as "a new paradigm in the field of Religious Pedagogy" (Manfred L. Pirner). This paper aims to strengthen this approach through a critical review. To achieve this, the theoretical foundations of Public Religious Pedagogy will be examined more closely in order to investigate their strengths and weaknesses. The result of these considerations is to expand historical sources and interdisciplinary references of Public Religious Pedagogy: It is necessary to interpret the concept more broadly. Finally, this article argues in favour of a critical and prophetic Public Religious Pedagogy.
\end{abstract}

Keywords Public Religious Pedagogy $\cdot$ Public theology $\cdot$ Critical theory $\cdot$ Civic education

During the last years, our social context has changed radically: Today, religious education takes place in an environment of social crises. Hans Mendl, Professor of Catholic Theology in Germany, states that the world's present perception is shaped by "the refugee movements of recent years", the "nationalisms emerging in many countries" as well as "terrorist threats, wars and the erosion of democratic systems" (Mendl 2019, p. 62). This situation raises a new paradigm called Public Religious Pedagogy. It can be seen as an attempt to reconceptualize religious education in the face of social transformations, which represents a fundamental challenge for Western societies. Due to this development, Public Religious Pedagogy gets increasing support within the scientific community.

In this essay, the following thesis is presented: The public orientation of religious education should be advocated, because the concept is an important supplement and a critical corrective to existing debates in religious education. However, Public Religious Pedagogy still lacks a critical punch and a utopian imagination. Following a well-known dictum of the political philosopher Raymond Geuss, it could be argued that Public Religious Pedagogy is, until now, neither realistic nor utopian enough to meet the current challenges adequately. Despite that, religious education in a global

Jan-Hendrik Herbst

jan-hendrik.herbst@tu-dortmund.de

1 Katholische Theologie (Praktische Theologie und Religionspädagogik), TU Dortmund,

Emil-Figge-Straße 50, Raum 2.305, 44227 Dortmund, Germany 
perspective needs to be grounded within a critical analysis of contemporary society; it needs to move towards utopian hope by providing religious education for global challenges (Kim 2015, p. 326).

\section{Public Theology: introductory remarks}

In recent years, Public Theology has formed as a significant theological program within the international debate (Bedford-Strohm 2018a; Kim and Day 2017; Vögele 1994). The term refers to Christian engagement in public debates. The assumption is that Christian traditions of value offer "complementary or supplementary approaches and even alternative solutions to the very complex issues facing societies today." (Kim 2011, p. 3) The goal is to influence political decisions in the sense of a Christian and humanitarian orientation. For instance, Public Theologian Heinrich Bedford-Strohm, who is the Council President of the German Protestant Church, is committed to supporting the rescue of refugees in the Mediterranean Sea (EKD 2019).

When dealing with Public Theology, it is necessary to mention that this term comprises a diverse and extensive tradition of theological works. The diversity of Public Theology results from the fact that it is active in different contexts and that a sensitivity for the respective social circumstances corresponds with the theological program (Meireis 2017, p. 3). The plurality of this theological program is already evident as the boundaries between concepts such as civil religion on the one hand and Liberation Theology as well as Political Theology on the other hand are not always clear (Torre 2015). Public Theology feeds itself from the sources of these traditions, so it is also understood as "Liberation Theology for a Democratic Society" (Bedford-Strohm 2018a). At the same time, efforts are made to distinguish between content and concepts, for example when Political Theology is combined with Carl Schmitt's anti-democratic state theory (Hidalgo 2018, p. 1). Even if there are certain differences regarding these forms of theology (Martinez 2001, p. 217, p. 251; Kim 2011, pp. 21-22; Lee 2015; Stackhouse 2004, 2015), they do not stand against each other, they even enrich each other.

German theologian Thorsten Meireis, who works at the Berlin Institute for Public Theology, has made important contributions to the international debate (e.g. Meireis and Schieder 2017). He underlines an "increasing dissemination and diversification" (Meireis 2017, p. 5) of the debate. In recourse to Dirk J. Smit (Princeton Theological Seminary), Meireis distinguishes six tradition lines of Public Theology, each of them following its own logic (ibid., p. 3; Smit 2007, 2013). Without unfolding these six lines in more detail, it should be pointed out that Political Theology established by Johann B. Metz, Dorothee Sölle and Jürgen Moltmann is also regarded as a form of Public Theology (Meireis 2017, p. 4). Explicit attempts can be found to redesignate these approaches as Public Theology (Paeth 2005; Moltmann 2015; Arens 2009, 2016). Furthermore, within the context of this article, it is particularly important to emphasize that theories inspired by Liberation Theology and founded on postcolonial theory are also included in these traditions (Meireis 2017, p. 3; e. g. Maluleke 2011). 


\section{Public Religious Pedagogy: bridging the gap}

Public theology as a quite new term has recently set important impulses for religious education (Pirner et al. 2016, 2018, 2019), for instance in contexts of interreligious learning (Pirner 2018a). It deals with the ambivalent role of religions within plural democracies from different ideological perspectives in educational contexts (Pirner 2016a, p. 3). This fills a blank space, a desideratum of research, since previously "in the otherwise rich international discourse around Public Theology, the intersection between Public Theology and education seems to have been widely neglected" (Pirner 2019a, p. 1). In the context of Religious Education, the recently developed concept 'Public Religious Pedagogy' is used "in analogy to Public Theology" (ibid., p. 4; Pirner 2019b). It could be understood:

"as a consequence and concretization of Public Theology in that it can acquaint students with religious motivations and perspectives for contributing to the common good and clarify the role of religions in the public sphere of pluralistic societies" (Pirner 2019a, p. 3).

The discussion about Public Religious Pedagogy has an international dimension, but it arises from the specific context of German discourses (ibid., p. 4; Könemann 2016; Schröder 2013, 2017; Grümme 2018a; Schlag 2012). It is situated within a debate about the political dimension of religious pedagogy and education (Pirner 2019b, pp. 43-47). In this context, Pirner argues that Public Religious Pedagogy has the potential "to become a new paradigm in the field of Religious Pedagogy" (ibid., p. 40).

Regarding Public Religious Pedagogy, however, it is striking that the traditions of Public Theology are not perceived in all their richness. Although attempts are made to establish an internationally employable concept, the German-language and Protestant tradition of Public Theology serves as the main reference (e.g. Wolfgang Huber or Heinrich Bedford-Strohm). Neither political-theological nor liberation-theological impulses are explicitly addressed. On the contrary, there is even a resolute demarcation: Thomas Schlag concedes, for example, that, in contrast to Political Theology or Liberation Theology, Public Theology does not only take a critical look at social conditions. It attempts to perceive the socio-economic circumstances "in their complexity" (Schlag 2014 , p. 7). This insinuates that socio-critical approaches imply a subcomplex analysis.

In Bernhard Grümme's "Departure into the Public Sphere? Reflections on the 'Public Turn' in Religious Pedagogy" (2018a), the author examines the problems and reductions of Public Religious Education (Grümme 2018a, pp. 15-46). His aim is not delegitimizing, but further developing the concept. With regard to Grümme, the question is raised how "a fundamentally critical perspective of society and reflections in political categories" (ibid., p. 22) can be executed within the framework of this type of Public Religious Education. Grümme critically reflects: "Where is the dynamic [...] theological impulse for social change [...]? From a liberation-theological perspective as well as from [...] debates about 'post-democracy' (Colin Crouch), this presupposed framework appears as an axiom that is not self-evident" (ibid., p. 26). This article follows Grümme's observations. It aims to give a critical impulse to the controversial debate about Public Religious Pedagogy: Problems, as well as open questions are addressed and possibilities for solving or answering them are presented. Essentially, this article is an attempt to support the concept as I sympathise with the concerns of a Public Religious Pedagogy. 


\section{About the necessity of Public Religious Pedagogy: religious education in times of social changes and crises}

As it was stressed in the introduction to this article, religious education is currently taking place within a critical environment as exemplified by keywords such as Post-Democratic Populism, Global Warming and Economization of Education (Herbst 2020b). Social inequalities and justice issues should also be named here. In order to be able to systematically incorporate this social context into religious education theories, readjustments at a basic theoretical level are necessary - as it will be shown now.

The main reason why religious education should respond to these contextual changes is the significant—if not crucial—role religion plays in contemporary crises and conflicts. This can be illustrated by three examples. Firstly, religion is of central importance for populist political strategies (Brittain 2018; Zúquete 2017; Marzouki et al. 2016). Forms of group-focused enmity such as racism and anti-Semitism are often deeply religious. This accruing problem can be traced back to religious textbooks and curricula (Rothgangel 2018; Spichal 2015). Similarly, different forms of religiosity correspond with different perspectives on global warming (Sachdeva 2016). In response to the international movement 'Fridays for Future', attempts are currently being made to highlight the public responsibility of religious education (Bederna 2019). Thirdly, the neoliberal economic system may have a religious structure (in a broad sense) itself (Gauthier and Martikainen 2013a, b). Therefore, resistance from sources of Christian tradition is also pleaded (Bucher 2019; Day 2016). There has been critical debate on the fact that the education sector is being economised. As well-known political theorist Martha Nussbaum states, the various crisis phenomena are interrelated:

Education based mainly on profitability in the global market magnifies these deficits [of democracies], producing a greedy obtuseness and a technically trained docility that threaten the very life of democracy itself, and that certainly impede the creation of a decent world culture (Nussbaum 2012, p. 142; Kim 2015, pp. 312-317).

It is becoming increasingly evident that these circumstances must be intensively reflected in scientific research about religious education. The programme of a Public Religious Education represents an attempt to account for this. On the one hand, socio-theoretical elements are included in order to understand the crises and their connection with religious education. Thus, Public Religious Education advances readjustments on a basic theoretical level. On the other hand, an active contribution of religious education is proposed in order to counter problematic developments and create a more humane society. In Pirner's words, this paragraph can be concluded on a positive note: "Religious Pedagogy needs to become a Public Religious Pedagogy, that is, more aware of its political implications and tasks" (Pirner 2019a, p. 5). With Public Religious Pedagogy it is possible to counteract the "blind spot" (Grümme 2019a, p. 56) of the political dimension of religious education that was created by the "increasing concentration on the aesthetic and cultural hermeneutic aspects of education" (ibid., p. 56; Pirner 2019a, b; Könemann and Mette 2013, p. 13). 


\section{Unresolved Questions and Problems: Public Religious Pedagogy is too little realistic and too little utopian at the same time}

Public Religious Pedagogy is necessary, yet not entirely unproblematic. This is already evident from the fact that there is a plurality of similar terms (Herbst 2019). For example, you will find the term "political religious pedagogy" (Könemann 2019) as well. This indicates that a consistent and consensual approach is missing so far. Nevertheless, this is not necessarily a problem; it also opens the opportunity for a controversial and productive debate about the aims and perspectives of Religious Pedagogy. This article is a critical contribution to this discussion. Unresolved questions and problems can be demonstrated using the example of a basic theory that is central for Public Religious Pedagogy.

John Rawl's political theory is of essential importance for Public Theology (BedfordStrohm 2018b) and Public Religious Pedagogy (Pirner 2017, pp. 90-92; Pirner 2018b, 2019a, p. 2). This Political Philosophy of Liberalism has been the central theoretical framework for Public Religious Pedagogy so far. ${ }^{1}$ For instance, Manfred Pirner notes: "In my view, which I share with Heinrich Bedford-Strohm [...], Rawls' model [...] is highly compatible with the perspectives of Public Theology and Public Religious Pedagogy" (Pirner 2017, p. 92). This results in some fundamental problems, which have to be named explicitly (Grümme 2019d, pp. 36-37; Grümme 2018a, pp. 21-26). Based on Geuss' critique of John Rawls (Geuss 1981, 2008, pp. 70-73, pp. 82-94; Menke 2010), it can be argued that Public Religious Pedagogy is too little critical and, at the same time, too little utopian (Geuss 2010, p. 429; Freyenhagen and Schaub 2010). It is too little critical, because it simply presupposes the liberal Western social and economic order without questioning it and its contradictions and power structures. The basic assumptions are too harmonistic and optimistic: It is assumed that dialogue and cooperation alone could lead to a more humane society (Pirner 2019a, pp. 1-2). The idea behind this is that the public discourse is, at least potentially, rational (in a liberal sense). However, this assumption is highly questionable in times of "Politics of Resentment" (Fukuyama 2018), "Affects of Democracy" (Mouffe 2018) and "Political Emotions" (Nussbaum 2015).

In addition, the individual is overly regarded as an isolated monad. The social conditionality of the learning subject must be given greater analytical consideration: The notion of the subject and education is too idealistic (Englert 2010). It is lacking any critical reflection of "structures of power, hegemonic structures as well as identity-logical structures [...] mechanisms of exclusions, stigmatization, and power" (Grümme 2019a, p. 61) the teachers themselves are involved in. Therefore, a more fundamentally critical consciousness is necessary, also requiring a substantial critique of today's democracies and of ways of humanizing them from the perspective of the biblical tradition-as Bernhard Grümme notes in reference to the theologian Jon Sobrino (Grümme 2019b, p. 170). Only then, religious education can contribute — as Public Religious Pedagogy demands— to the (ongoing) humanization of democracy.

A confrontation with postliberal theology, radical orthodoxy (Bell 2015) and radical theory of democracy still seem to be lacking (Crockett 2011; Robbins 2011; Cavanaugh 2016, 2011). John Hull's critical analysis of money culture provides an example of what

\footnotetext{
1 In addition to John Rawls, Jürgen Habermas' social theory is also an important point of reference for Public Religious Pedagogy. For reasons of space, I cannot discuss this theory here.
} 
critical social analysis can mean theologically (Hull 2009). Norbert Mette has made it clear that this has important consequences for religious education (Mette 2013).

At the same time, Public Religious Pedagogy is too little utopian; after all, its transforming potential is being tapped in a school reform - as Geuss also states regarding Rawls (Geuss 2010, p. 429). Only if "the radicalism of the Christian message" (Grümme 2019a, p. 63) is taken seriously, this problem can be overcome, and a utopian imagination can be developed (Englert 2008). In order to oppose the danger of neutralizing the "prophetic dimensions of theology" (Grümme 2019a, p. 63), this article pleads for a wider concept of Public Religious Pedagogy. The historical sources as well as the interdisciplinary references of the concept should be interpreted more broadly.

\section{Diachronic perspective: the concept of a critical-emancipatory religious education as a historical resource of Public Religious Pedagogy}

The reform decade of religious education between 1965 and 1975, also known as the political phase in Germany, is an important starting point for Public Religious Pedagogy (Pirner 2019b, pp. 40-47). The central point of reference is Sigurd Daecke, who himself speaks of a "'Public Religious Education', which corresponds to a 'public', 'empirical-critical' and 'political' theology" (quoted from ibid., p. 42). However, it is surprising that the diverse and rich approaches to political and critical religious education in this phase are hardly systematically implemented as a reference point for Public Religious Education. They are neither considered nor adequately adapted. Daecke himself also refers to this tradition, for example to Johann B. Metz (ibid., p. 42). If Public Religious Pedagogy does not consciously exclude the historical diversity of these approaches, there is the chance of preserving critical punch and utopian imagination. This can be illustrated by two examples.

On the one hand, the political, critical-emancipatory religious pedagogy of the 1960s and 1970s should be adapted. Educators like Siegfried Vierzig, Folkert Rickers or Gert Otto on the Protestant side and Hubertus Halbfas, Adolf Exeler or Theodor Filthaut on the Catholic side have conceptualized religious education in relation to public responsibility and democracy. In the spirit of the Second Vatican Council and the student protests of "1968", two important strands of a political, public and critical religious education have emerged as "Problem-Oriented Religious Education" (Rothgangel 2014, pp. 69-71) and correlation didactics, which are not yet implemented intensively enough. These conceptions followed the "Political Theology [...] and the critical theory of the Frankfurt School of sociology" (ibid., p. 70). "The goal of this form of Religious Education was "political enlightenment' [...], the detection of power relations which render freedom and justice impossible, as well as emancipation" (ibid., p. 70). All in all, the history of a Public Theology and a Public Religious Pedagogy is not considered systematically enough - not even in its international dimension (Herbst 2020a).

On the other hand, it could also be connected to a critical "theory of Bildung" (Lachmann and Rothgangel 2014, p. 37). Well-known names that stand for such a tradition in Germany are Helmut Peukert, Heinz-Joachim Heydorn and Wolfgang Klafki (ibid., pp. 36-38). Inside the international context, the significance of Paulo Freire is certainly exorbitant (Ahme 2020). Paulo Freire's critical pedagogy has left deep traces in international educational science and religious pedagogy up to this day (Byrne 2011). The Christian and theological sources and prophetic dimensions of Paulo Freires' educational approach 
are being discovered lately in critical pedagogy (McLaren and Jandrić 2018; McLaren and Jandrić 2017; McLaren 2015). "For Freire, critical consciousness (conscientization) cannot be divorced from Christian consciousness" (McLaren and Jandrić 2018, p. 256).

These tracks could be followed today; they can retrospectively inspire a critical and utopian Public Religious Pedagogy. Overall, it can be said that a comprehensive review and a critical-constructive look at the past are necessary today. Of course, these approaches are not without any problems and cannot be simply adapted. But a critical re-reading is worthwhile today as one can learn from its mistakes as well as from its unfulfilled potentials (Gärtner and Herbst 2020a). For example, one can demonstrate a poststructurally reflected revision of the concept of emancipation (Grümme 2020) or a theological discovery of the political dimension of religious education (Könemann 2019). And a critical analysis of one's own position and involvement in the social interrelationships can take lessons from this, too (Gautier 2020).

\section{Synchronous perspective: the renewal of critical-emancipatory political education as a source for interdisciplinary dialogue}

Public Religious Pedagogy is obviously an interdisciplinary project (Pirner 2016b, p. 335). As it has already become apparent, there are strong references to theology, pedagogy and sociology. These references need to be strengthened, intensified and differentiated. For example, - in addition to the Frankfurt School-poststructuralist, postcolonial and postmarxist theoretical approaches should play a central role for Public Religious Pedagogy. Bernhard Grümme also advocates such an approach:

"a critical dialogue by means of Foucault's discourse analysis as well as the sociotheoretical approaches in the tradition of critical theory [...] can indicate blind spots and overlooked mechanisms of power, exclusion, and hegemony both in the church's own praxis and in its theory" (Grümme 2019a, p. 61; Grümme 2018a, p. 26).

Thus, genuine alternatives should be discussed controversially within the framework of a variety of theories. Alternative ways of thinking could be developed in relation to Jacques Rancière, Judith Butler or Bonnie Honig (Lloyd and True 2017). These approaches can be applied very productively to educational theoretical considerations as well (Bünger and Meyer 2018, p. 569). For instance, Foucault's theory of power, which is further developed within the framework of Governmentality Studies, can be critically related to education (Grümme 2018b, pp. 574-577).

An important field of interdisciplinary dialogue, which aims more strongly at educational practice, has been visited only to a limited extent so far: The exchange with civic education and political didactics. Current debates reveal "that the contents and objectives of Religious Education itself are of considerable political relevance, and therefore, always be expressed in categories which are sensitive to political issues." (Wermke 2014, p. 191) One example shows how Public Religious Pedagogy can learn from civic education: The Frankfurt Declaration for a Critical-Emancipatory Political Education (Eis et al. 2016). The Frankfurt Declaration consists of six criteria composing critical-emancipatory civic education. This article argues for the inclusion of these criteria in order to determine a public and political religious education. 
Firstly, it is necessary to sensitize oneself for the crises of the present. Education has the task to contribute to a more democratic society and to help shape a socio-ecological transformation. Secondly, it is a matter of making conflicts and dissent visible in society. "Controversy, understood as principle of teaching and learning, is not only the documentation of different positions alongside already existing and influential perspectives, it deals with contentious issues and underlying dissent, reveals opposition and encourages critical thinking" (ibid., p. 74). Thirdly, power structures must be analysed and disclosed. This requires a socio-theoretical examination of relations of dominance as well as hierarchies. "Political Education discusses how exclusions are produced and how barriers are created: between the private and public sphere, between the social and the political, legitimate and illegitimate, experts and lay people" (ibid., p. 74). Fourthly, it is about reflecting one's own involvement in social relationships. As a researcher and teacher, one is integrated into power structures. Even if one criticizes them and tries to overcome them, this must not be ignored. An important example of this is "the neo-liberal approach of the "self-entrepreneur' or 'self-responsible' consumer" (ibid., p. 75) which is becoming increasingly important for educational institutions. Fifthly, critical emancipatory education empowers participants to deal constructively with experiences of oppression. Feelings and body experiences are not excluded rationally. "This implies the participation of the learners in planning and reflecting on their own learning processes" (ibid., p. 75). Lastly, critical emancipatory education aims at helping to change society. Otherwise there is a danger that the criticised conditions will be consolidated and doubled. "Political action gives rise to new possibilities of experience, thinking, and establishing (new) political alternatives" (ibid., p. 75). Religious education can make a specific contribution to pedagogical debates especially when theological concepts become central to them (e.g. "hope", Hodgson et al. 2017; Gärtner and Herbst 2020c, pp. 636-637).

\section{Conclusion: how religious education could get a critical and utopian edge}

In this article it was pointed out that Public Religious Pedagogy is an important programme, but it still contains some difficulties. In contrast to a monism of liberal approaches, an interdisciplinary variety of theories must be strengthened today. It was particularly advocated that the more recent developments within the framework of critical theories should be utilized from the perspective of religious education. For this to succeed, it is necessary to revisit a Critical-Emancipatory Religious Education in a diachronic perspective; from a synchronous perspective, there was a plea for interdisciplinary dialogue with a criticalemancipatory Political Education.

But what should be the practical consequences and results of these considerations? This question, which cannot be answered sufficiently here, indicates a desideratum. However, it should at least be pointed out that a new anthology made an attempt to fill this void (Gärtner and Herbst 2020a, pp. 421-609). One example for a critical approach to religious education is presented by an Assistant Professor of Political Didactics, Alexander Wohnig (2017a, b, 2019). He did a qualitative analysis of the citizenship education project 'compassion' which is common in German schools and conducted in classes of Religious Education. This concept of social learning in community projects aims at "get[ting] young people involved in politics as well as to teach them participation" (Wohnig 2017a, b, p. 244). Wohnig points out that "these programs, which try to encourage democratic citizenship, 
are more characterized by behavioral goals and the aspiration to attain a prosocial attitude change than by aiming at democratic behavior." (ibid.) One main problem is the missing analysis of current power structures in a society of the "activating state"-as Wohnig calls it in relation to sociological theories of Stephan Lessenich and Michel Foucault. He criticizes how those projects don't reflect the political context and how "personal responsibility seems to be more important than critical analysis and truly political participation." (ibid.) He thinks that a wrong conceptualization of those projects is the "origin of young people's apolitical perceptions of community work and common practices of service learning." (ibid.) In contrast to that, he conceptualizes a form of citizenship education which offers political and not only social learning.

Against the background of the considerations mentioned above, this article pleads for a critical Public Religious Pedagogy (Grümme 2019c, p. 49) or prophetic Public Religious Pedagogy_following a "prophetic Public Theology" (Williams 2014). Such an approach is also due, following the confrontation with past approaches developed especially in the long 1960s within the framework of Religious Pedagogy. Such a reference to the past could be polemically expressed in a phrase like "Make Critical Theory Great Again" (Gärtner and Herbst 2020b, p. 7). But, obviously, a retrogression like that cannot be intended in times of Retrotopia (Bauman 2017). In contrast, a future-oriented return to the past is necessary. However, it cannot be decided at this point whether the programme is meaningful and sustainable in the long run-rather, the future itself will prove this right or wrong (Gärtner and Herbst 2020c, pp. 648-649; Herbst 2020b).

Acknowledgements Open Access funding provided by Projekt DEAL. Regarding hints and feedback, I thank Claudia Gärtner, Linn Gogarten, Bernhard Grümme, Paulina Szymankiewicz, Madeline Stratmann and Stephan Tautz.

Open Access This article is licensed under a Creative Commons Attribution 4.0 International License, which permits use, sharing, adaptation, distribution and reproduction in any medium or format, as long as you give appropriate credit to the original author(s) and the source, provide a link to the Creative Commons licence, and indicate if changes were made. The images or other third party material in this article are included in the article's Creative Commons licence, unless indicated otherwise in a credit line to the material. If material is not included in the article's Creative Commons licence and your intended use is not permitted by statutory regulation or exceeds the permitted use, you will need to obtain permission directly from the copyright holder. To view a copy of this licence, visit http://creativecommons.org/licenses/by/4.0/.

\section{References}

Ahme, B. (2020). Das Büro für Bildungsfragen des Ökumenischen Rates der Kirchen im Kontext der globalen Rezeption Paulo Freires. Zeitschrift für Pädagogik und Theologie (not published yet).

Arens, E. (2009). Vom Schrei zur Verständigung. Politische Theologie als öffentliche Theologie. In T. Polednitschek, M. J. Rainer \& J. A. Zamora (Eds.), Theologisch-politische Vergewisserungen (pp. 129-138). Münster: LIT.

Arens, E. (2016). Going public_-Öffentliche Religionen und Öffentliche Theologie. In E. Arens, M. Baumann \& A. Liedhegener (Eds.), Integrationspotenziale von Religion und Zivilgesellschaft. Theoretische und empirische Befunde (pp. 19-69). Zürich: Pano.

Bauman, Z. (2017). Retrotopia. Cambridge: Polity Press.

Bederna, K. (2019). Every day for Future. Theologie und religiöse Bildung für nachhaltige Entwicklung. Ostfildern: Matthias Grünewald.

Bedford-Strohm, H. (2018a). Liberation Theology for a Democratic Society: Essays in Public Theology. Collected by Michael Mädler and Andrea Wagner-Pinggéra. Münster: LIT

Bedford-Strohm, H. (2018b). Auf dem Weg zu einer theologischen Theorie der Gerechtigkeit. Leipzig: EVA. 
Bell, D. M., Jr. (2015). Postliberalism and radical orthodoxy. In C. Hovey \& E. Phillips (Eds.), The Cambridge Companion to Christian Political Theology (pp. 110-132). Cambridge: Cambridge University Press.

Brittain, C. C. (2018). Racketeering in religion: Adorno and evangelical support for Donald Trump. Critical Research on Religion, 6, 269-288.

Bucher, R. (2019). Christentum im Kapitalismus. Wider die gewinnorientierte Verwaltung der Welt. Würzburg: echter.

Bünger, C., \& Mayer, R. (2018). Critical theory and its aftermath. In P. Smeyers (Ed.), International handbook of philosophy of education (pp. 569-590). Dordrecht: Springer.

Byrne, C. (2011). Freirean critical pedagogy's challenge to interfaith education: What is interfaith? What is education? British Journal of Religious Education, 33(1), 47-60.

Cavanaugh, W. (2011). A politics of vulnerability. In W. Cavanaugh (Ed.), Migrations of the holy: God, state, and the political meaning of the Church (pp. 170-195). Cambridge: William B. Eerdmans.

Cavanaugh, W. (2016). A politics of multiplicity: Augustine and radical democracy. In W. Cavanaugh (Ed.), Field hospital. The Church's engagement with a wounded world (pp. 150-156). Cambridge: William B. Eerdmans.

Crocket, C. (2011). Radical democracy and political theology. New York: Columbia University Press.

Day, K. (2016). Religious resistance to neoliberalism. Womanist and Black Feminist perspectives. New York: Palgrave Macmillan.

Eis, A., Lösch, B., Schröder, A., \& Steffens, G. (2016). Frankfurt declaration. For a critical-emancipatory political education. Journal of Social Science Education, 15(1), 74-75.

Englert, R. (2008). Das Christentum und der Geist der Utopie. Katechetische Blätter, 133, 4-8.

Englert, R. (2010). Vorsicht Schlagseite! Was im Bildungsdiskurs der Religionspädagogik gegenwärtig zu kurz kommt. $T P Q, 158,123-131$.

Evangelische Kirche Deutschland (EKD). (2019). Letting people drown is not an option for Europe. Retrieved 24 October, 2019, from https://www.ekd.de/en/Letting-people-drown-is-not-an-option-forEurope-1353.htm.

Freyenhagen, F., \& Schaub, J. (2010). Hat hier jemand gesagt, der Kaiser sei nackt? Eine Verteidigung der Geussschen Kritik an Rawls idealtheoretischem Ansatz. Deutsche Zeitschrift für Philosophie, 58(3), 457-477.

Fukuyama, F. (2018). Identity: The demand for dignity and the politics of resentment. New York: Farrar, Straus and Giroux.

Gärtner, C., \& Herbst, J.-H. (Eds.). (2020). Kritisch-emanzipatorische Religionspädagogik. Diskurse zwischen Theologie, Pädagogik und Politischer Bildung. Wiesbaden: Springer.

Gärtner, C. \& J.-H. Herbst (2020b). Einleitung: Zurück in die Zukunft? In C. Gärtner \& J.-H. Herbst (Eds.), Kritisch-emanzipatorische Religionspädagogik. Diskurse zwischen Theologie, Pädagogik und Politischer Bildung (pp. 1-20). Wiesbaden: Springer.

Gärtner, C. \& J.-H. Herbst (2020c). Kritisch-emanzipatorische Religionspädagogik: Offene Fragen und programmatischer Ausblick. In C. Gärtner \& J.-H. Herbst (Eds.), Kritisch-emanzipatorische Religionspädagogik. Diskurse zwischen Theologie, Pädagogik und Politischer Bildung (pp. 633-649). Wiesbaden: Springer.

Gauthier, F., \& Martikainen, T. (2013). Religion in consumer society. Brands, consumers and markets. London: Routledge.

Gauthier, F., \& Martikainen, T. (Eds.). (2013). Religion in the neoliberal age: Political economy and modes of governance. London: Routledge.

Gautier, D. (2020). Irritierbarkeit. Eine theologische Überlegung zur kritisch-emanzipatorischen Religionspädagogik. In C. Gärtner \& J.-H. Herbst (Eds.), Kritisch-emanzipatorische Religionspädagogik. Diskurse zwischen Theologie, Pädagogik und Politischer Bildung (pp. 403-420). Wiesbaden: Springer.

Geuss, R. (1981). The idea of a critical theory. Cambridge: CUP.

Geuss, R. (2008). Philosophy and real politics. Princeton: PUP.

Geuss, R. (2010). Realismus, Wunschdenken, Utopie. Deutsche Zeitschrift für Philosophie, 58(3), 419-429.

Grümme, B. (2018a). Aufbruch in die Öffentlichkeit? Reflexionen zum ,public turn ' in der Religionspädagogik. Bielefeld: transcript.

Grümme, B. (2018b). Power, equality and differency in religious pedagogy: The underrated relation. In $R E A$ proceedings (pp. 573-586). Retrieved 10 December, 2019, from https://religiouseducation.net/papers/ proceedings-REA2018.pdf.

Grümme, B. (2019). Educational justice as subject matter of public religious pedagogy. In M. L. Pirner, J. Lähnemann, W. Haußmann, \& S. Schwarz (Eds.), Public theology perspectives on religion and education (pp. 55-66). New York: Routledge. 
Grümme, B. (2019). Religionsunterricht als Beitrag zur Bildung in der Demokratie. Zeitschrift für Pädagogik und Theologie, 71(2), 159-172.

Grümme, B. (2019). Religiös und politisch zweisprachig - was heißt das? Sprach- und Gesprächsfähigkeit im Kontext politischer Religionspädagogik. Theo-Web, 18(2), 42-51.

Grümme, B. (2019d). Übersetzung ,inmitten von Ruinen“ (Judith Butler). Nachdenkliche Anmerkungen zu einem religionspädagogischen Postulat. In S. Haußmann, W. Roth, A. Schwarz \& C. Tribula (Eds.), EinFach Übersetzen. Theologie und Religionspädagogik in der Öffentlichkeit und für die Öffentlichkeit. (pp. 35-44). Stuttgart: Kohlhammer.

Grümme, B. (2020). Problemorientierter Religionsunterricht: Vernachlässigtes Potential für eine politisch sensible Religionspädagogik in postdemokratischen Zeiten? In C. Gärtner \& J.-H. Herbst (Eds.), Kritisch-emanzipatorische Religionspädagogik. Diskurse zwischen Theologie, Pädagogik und Politischer Bildung (pp. 33-53). Wiesbaden: Springer.

Herbst, J. H. (2019). Konturen einer, neuen politischen Religionspädagogik'? Begriffstheoretische Betrachtungen einer zerfaserten Debatte. Österreichisches Religionspädagogisches Forum, 27(1), $28-41$.

Herbst, J.-H. (2020a). Politische Religionspädagogik in transnationaler Perspektive. Rekonstruktion von Grundlinien des Wissenstransfers in der katholischen Religionspädagogik der langen 1960er-Jahre. Zeitschrift für Pädagogik und Theologie (not published yet).

Herbst, J.-H. (2020b). Zurück zu einer kritisch-emanzipatorischen Religionspädagogik? Religiöse Bildung in Zeiten sozialer Umbrüche und Krisen. Religionspädagogische Beiträge 1 (not published yet).

Hidalgo, O. (2018). Politische Theologie. Beiträge zum untrennbaren Zusammenhang zwischen Religion und Politik. Wiesbaden: Springer.

Hodgson, N., J. Vlieghe \& P. Zamojski (2017). Post-Critique. A Conversation. In N. Hodgson, J. Vlieghe \& P. Zamojski (Eds.), Manifesto for a Post-Critical Pedagogy (pp. 71-101). Retrieved 10 December, 2019, from https://punctumbooks.com/titles/manifesto-for-a-post-critical-pedagogy.

Hull, J. (2009). Blaspheming the money god. RE Today, 27(1), 4-5.

Kim, H.-S. (2015). Seeking critical hope in a global age: Religious education in a global perspective. Religious Education, 110(3), 311-328.

Kim, S., \& Day, K. (2017). A companion to public theology (Brill's companions to modern theology 1). Leiden: Brill.

Kim, S. (2011). Theology in the public sphere: Public theology as a catalyst for open debate. London: SCM Press.

Könemann, J. \& Mette, N. (2013). Einleitung 2013. In Könemann, J. \& Mette, N. (Eds.), Bildung und Gerechtigkeit. Warum religiöse Bildung politisch sein muss (pp.). Ostfildern: Grünewald 2013.

Könemann, J. (2016). Theologie, Kirche und Öffentlichkeit. In J. Könemann \& S. Wendel (Eds.), Religion, Öffentlichkeit, Moderne. Transdisziplinäre Perspektiven (pp. 129-152). Bielefeld. Transcript.

Könemann, J. (2019). Bildungsgerechtigkeit im Kontext einer politischen Religionspädagogik. Österreichisches Religionspädagogisches Forum, 27(1), 42-56.

Lachmann, R., \& Rothgangel, M. (2014). II Understanding and tasks of the subject-related didactics of Religious Education. In M. Rothgangel, R. Lachmann, F. Schweitzer, G. Adam, \& T. Schlag (Eds.), Basics of religious education (pp. 29-44). Göttingen: V\&R.

Lee, H. J. (2015). Public Theology. In C. Hovey \& E. Phillips (Eds.), The Cambridge companion to Christian political theology (pp. 44-65). Cambridge: Cambridge University Press.

Lloyd, V., \& True, D. (2017). What is the Political Theology Canon? Editorial. Political Theology, $18(7), 539-541$.

Maluleke, T. S. (2011). Reflections and resources. The elusive public of public theology: A response to William Storrar. International Journal of Public Theology, 5, 79-89.

Martinez, G. (2001). Confronting the mystery of god: Political, liberation, and public theologies. London: Continuum.

Marzouki, N., McDonnell, D., \& Roy, O. (Eds.). (2016). Saving the people: How populists hijack religion. London: Hurst \& Company.

McLaren, P., \& Jandrić, P. (2017). From liberation to salvation: Revolutionary critical pedagogy meets liberation theology. Policy Futures in Education, 5, 620-652.

McLaren, P., \& Jandrić, P. (2018). Paulo freire and liberation theology: The Christian consciousness of critical pedagogy. Vierteljahrsschrift für wissenschaftliche Pädagogik, 94, 246-264.

McLaren, P. (2015). Pedagogy of insurrection: From resurrection to revolution. New York: Peter Lang.

Meireis, T., \& Schieder, R. (Eds.). (2017). Religion and democracy. Studies in public theology. BadenBaden: Nomos. 
Meireis, T. (2017). Öffentlichkeit. Eine kritische Revision (Antrittsvorlesung an der Theologischen Fakultät der Humboldt-Universität zu Berlin, 21.06.2017). Retrieved 24 October, 2019, from https ://www.theologie.hu-berlin.de/de/professuren/professuren/ethik/Aktuelles/offentlichkeitmeireis.pdf.

Mendl, H. (2019). Weltverantwortung. Politisch und global lernen im RU. Österreichisches Religionspädagogisches Forum, 27(1), 57-72.

Menke, C. (2010). Neither Rawls Nor Adorno: Raymond Geuss' Programme for a 'Realist' Political Philosophy. European Journal of Philosophy, 18(1), 139-147.

Mette, N. (2013). Religiöse Erziehung und Bildung im Kontext der „Geldkultur“. In T. Krobath, A. Lehner-Hartmann, \& R. Polak (Eds.), Anerkennung in religiösen Bildungsprozessen. Interdisziplinäre Perspektiven (pp. 277-287). Göttingen: V\&R.

Moltmann, J. (2015). European political theology. In C. Hovey \& E. Phillips (Eds.), The Cambridge companion to Christian political theology (pp. 3-22). Cambridge: Cambridge University Press.

Mouffe, C. (2018). Affects of democracy. Critique \&Humanism, 49(1), 61-70.

Nussbaum, M. (2010). Not for profit. Why democracy needs the humanities. Princeton: PUP.

Nussbaum, M. (2015). Political emotions. Why love matters for justice. Cambridge: HUP.

Paeth, S. R. (2005). Jürgen Moltmann's public theology. Political Theology, 6, 215-234.

Pirner, M. L. (2016). Introduction. In M. L. Pirner, J. Lähnemann, \& H. Bielefeldt (Eds.), Human rights and religion in educational contexts (pp. 3-10). Cham: Springer.

Pirner, M. L. (2016). Conclusion: Human rights and religion in educational contexts. Foundations and conceptional perspectives. In M. L. Pirner, J. Lähnemann, \& H. Bielefeldt (Eds.), Human rights and religion in educational contexts (pp. 335-346). Cham: Springer.

Pirner, M. L. (2017). Öffentliche Religionspädagogik im globalen Horizont. Perspektiven für evangelische Schulen. In A. Scheunpflug, H. Simojoki \& M. Schreiner (Eds.). Evangelische Schulen und religiöse Bildung in der Weltgesellschaft. Die Bamberger Barbara-Schadeberg Vorlesungen (pp. 83-95). Münster: Waxmann.

Pirner, M. L. (2018). Introduction. In M. L. Pirner, J. Lähnemann, W. Haussmann, \& S. Schwarz (Eds.), Public theology, religious diversity and interreligious learning: Contributing to the common good through religious education (pp. 1-7). London: Routledge.

Pirner, M. L. (2018b). Religionsunterricht zwischen politischer Abstinenz und Funktionalisierung. Perspektiven einer Öffentlichen Religionspädagogik. Die Gelbe 1 (Heilsbronn: RPZ), 43-69.

Pirner, M. L. (2019). Introduction. In M. L. Pirner, J. Lähnemann, W. Haußmann, \& S. Schwarz (Eds.), Public theology perspectives on religion and education (pp. 1-9). New York: Routledge.

Pirner, M. L. (2019). Public religious pedagogy_An emerging new paradigm? In M. L. Pirner, J. Lähnemann, W. Haußmann, \& S. Schwarz (Eds.), Public theology perspectives on religion and education (pp. 39-54). New York: Routledge.

Pirner, M. L., Lähnemann, J., \& Bielefeldt, H. (Eds.). (2016). Human rights and religion in educational contexts. Cham: Springer.

Pirner, M. L., Lähnemann, J., Haussmann, W., \& Schwarz, S. (Eds.). (2018). Public theology, religious diversity and interreligious learning: Contributing to the common good through religious education. London: Routledge.

Pirner, M. L., Lähnemann, J., Haussmann, W., \& Schwarz, S. (Eds.). (2019). Public theology perspectives on religion and education. London: Routledge.

Robbins, J. W. (2011). Radical political theology: Religion and politics after liberalism. New York: Columbia University Press.

Rothgangel, M. (2014). IV. Conceptions of religious education and didactical structures. In M. Rothgangel, R. Lachmann, F. Schweitzer, G. Adam, \& T. Schlag (Eds.), Basics of religious education (pp. 63-80). Göttingen: V\&R.

Rothgangel, M. (2018). Anti-semitism as a challenge for religious education. In E. Aslan \& M. Rausch (Eds.), Religious education (pp. 35-51). Wiesbaden: Springer.

Sachdeva, S. (2016). Religious identity, beliefs, and views about climate change. Oxford Research Encyclopedia of Climate Science. Retrieved 24 October, 2019, from https://dx.doi.org/10.1093/acref ore/9780190228620.013.335.

Schlag, T. (2012). Öffentliche Kirche: Grunddimensionen einer praktisch-theologischen Kirchentheorie. Zürich: Theologischer Verlag Zürich.

Schlag, T. (2014). Wer hat hier das Sagen? Kirche in der Demokratie und Demokratie in der Kirche. Vortrag auf der Herbstkonferenz Bad Boll. Retrieved 24 October, 2019, from https://www.herbs tkonferenz.info/wp-content/uploads/2014/12/2014-10-18-Thomas-Schlag-Bad-Boll-Kirche-undDemokratie.pdf.

Schröder, B. (2013). Öffentliche Religionspädagogik. Perspektiven einer theologischen Disziplin. Zeitschrift für Theologie und Kirche, 110, 109-132. 
Schröder, B. (2017). Theologische Bildung im öffentlichen Raum. In T. Schlag \& J. Suhner (Eds.), Theologie als Herausforderung religiöser Bildung. Bildungstheoretische Orientierungen zur Theologizität der Religionspädagogik (pp. 151-178). Stuttgart: Kohlhammer.

Smit, D. J. (2007). Notions of the public and doing theology. International Journal of Public Theology, $1,431-454$.

Smit, D. J. (2013). The paradigm of public theology-Origins and development. In H. Bedford-Strohm, F. Höhne, \& T. Reitmeier (Eds.), Contextuality and intercontextuality in public theology (pp. 11-23). Münster: LIT.

Spichal, J. (2015). Vorurteile gegen Juden im christlichen Religionsunterricht. Eine qualitative Inhaltsanalyse ausgewählter Lehrpläne und Schulbücher in Deutschland und Österreich. Göttingen: V\&R Unipress.

Stackhouse, M. (2004). Civil religion, political theology and public theology: What's the difference? Political Theology, 5(3), 275-293.

Stackhouse, M. (2015). Zivilreligion, Politische Theologie und Öffentliche Theologie. Was ist der Unterschied? In F. Höhne \& F. V. Oorschot (Eds.), Grundtexte Öffentlicher Theologie (pp. 51-70). Leipzig: EVA.

Torre, M. A. D. L. (2015). Liberation theology. In C. Hovey \& E. Phillips (Eds.), The Cambridge companion to Christian political theology (pp. 23-43). Cambridge: Cambridge University Press.

Vögele, W. (1994). Zivilreligion in der Bundesrepublik Deutschland. Gütersloh: C. Kaiser.

Wermke, M. (2014). VI. Religion in school outside Religious Education. In M. Rothgangel, R. Lachmann, F. Schweitzer, G. Adam, \& T. Schlag (Eds.), Basics of religious education (pp. 95-112). Göttingen: V\&R.

Williams, B. (2014). Prophetic public theology. Review and Expositor, 11(2), 159-170.

Wohnig, A. (2017a). Political learning by social engagement? Chances and risks for citizenship education. Citizenship, Social and Economics Education, 15(3), 244-261.

Wohnig, A. (2017). Zum Verhältnis von sozialem und politischem Lernen. Eine Analyse von Praxisbeispielen politischer Bildung. Wiesbaden: Springer.

Zúquete, J. P. (2017). Populism and religion. In C. R. Kaltwasser, P. Taggart, P. Ochoa Espejo, \& P. Ostiguy (Eds.), The Oxford handbook of populism. Oxford: OUP.

Publisher's Note Springer Nature remains neutral with regard to jurisdictional claims in published maps and institutional affiliations. 